\title{
Archaeologia
}

http://journals.cambridge.org/ACH

Additional services for Archaeologia:

Email alerts: Click here

Subscriptions: Click here

Commercial reprints: $\underline{\text { Click here }}$

Terms of use : $\underline{\text { Click here }}$

\section{III.-_On a Grant of Arms under the Great Seal of Edward IV. to Louis de Bruges, seigneur de la Gruthuyse and earl of Winchester, 1472, with some remarks on the arms of English earldoms}

\author{
W. H. St. John Hope
}

Archaeologia / Volume 56 / Issue 01 / January 1898, pp 27 - 38

DOI: 10.1017/S0261340900003830, Published online: 25 January 2012

Link to this article: http://journals.cambridge.org/abstract S0261340900003830

How to cite this article:

W. H. St. John Hope (1898). III.-On a Grant of Arms under the Great Seal of Edward IV. to Louis de Bruges, seigneur de la Gruthuyse and earl of Winchester, 1472, with some remarks on the arms of English earldoms. Archaeologia, 56, pp 27-38 doi:10.1017/S0261340900003830

Request Permissions : $\underline{\text { Click here }}$ 
III.-On a Grant of Arms under the Great Seal of Edward IV. to Louis de Bruges, seigneur de la Gruthuyse and earl of Winchester, 1472, with some remarks on the arms of English earldoms. By W. H. S'т. Јонм Hоре, Esq., M.A.

Read December 16, 1897.

The document which I have the honour to exhibit to the Society is a grant of arms under letters patent of Edward IV. to a foreigner, Louis de Bruges, seigneur de la Gruthuyse, who was created earl of Winchester in 1472.

Every grant of arms is generally in itself a more or less interesting document, but there are, as I shall hope to show, several reasons why this is of greater interest than usual.

In vol. xxvi. of Archaeologia is printed a communication from Sir Frederic Madden, read before the Society on 12th June, 1834, entitled "Narratives of the arrival of Louis de Bruges, seigneur de la Gruthuyse, in England, and of his creation as earl of Winchester, in 1472."

Sir Frederic Madden's paper, besides containing a succinct biography of Louis de Bruges himself, describes fully the circumstances which led the king of England to invest a foreigner with an English earldom and confer upon him a special grant of arms.

As a recapitulation of these is necessary for the elucidation of the document under notice, I will relate the facts as briefly as I can.

In October, 1470, after the reverse of fortune by which Edward IV. was obliged to leave his crown and kingdom in the hands of the earl of Warwick, he set sail, together with his brother Richard, duke of Gloucester, the queen's brother Anthony, lord Scales, the lord Hastings, the king's chamberlain, and some few hundred followers, " in three small vessels for the dominions of his brother-in-law, the duke of Burgundy, under whose protection his only hope of safety seemed to lie."

a Pp. 265-286.

E 2 
Edward "had not long quitted the coast before his vessels were descried by some piratical ships belonging to the Easterlings, which gave chace, and it was with difficulty that the King and his companions reached the port of Alcmaer, about six leagues to the north of Haerlem, into which the Easterlings, from the superior size of their ships, and the tide being low, could not follow them. In this peril, with the enemy anchored at a short distance, awaiting only the return of the tide to make Edward a captive, it was very fortunate for the King, that the Governor of Holland under the Duke of Burgundy, Louis de Bruges, Seigneur de la Gruthuyse, happened to be at the time on the spot. On being informed of Edward's danger, he immediately went to the King's vessel, welcomed him with every mark of respect, and conducted him to the Hague, where he entertained the King at his own expense from the 9th October to the 26th December, when they set forward together to the town of Aerdenbourg. The following day they arrived at the Château of Gruthuyse, situated at Oostcamp, a village distant about a mile from the town of Bruges, and after stopping there two days, proceeded to Aire, in Artois, where the mother-in-law of the Duke of Burgundy (Edward's sister) was dwelling. After receiving from the Duke the strongest assurances of assistance, Edward returned to Bruges on the 13th January, 1470-1, and was lodged, with a part of his suite, at the Hotel of Gruthuyse, until the 19th of the following month, when he departed for Zeeland, where the ships furnished by the duke for his return to England awaited him." a

The Louis de Bruges to whom the king of England thus became so greatly indebted was born about 1422, and succeeded his father, John de Bruges, as seigneur de la Gruthuyse, prince of Steynhuyse, and lord of Avilghem, Hamste, Oostcamp, Bevern, etc. about 1443. He became cupbearer to Philip the Good, duke of Burgundy, in 1449, and in 1452 was made governor of Bruges. He was knighted in the following year, and in 1461 the Order of the Golden Fleece was conferred upon him. He held various offices of trust under the duke of Burgundy, and in October, 1466, was joint ambassador to England to conclude the treaty of peace and settle the conditions of the marriage between the duke's son, Charles the Bold, and the princess Margaret of York. It was probably during his visit that he first made the king's acquaintance. In 1470, as we have already seen, Louis was chiefly responsible for saving Edward from a possible captivity, and in contributing to his restoration to the throne of England.

Early in 1472 an embassy from Edward arrived at Bruges, and was received and entertained by the seigneur de la Gruthuyse. 

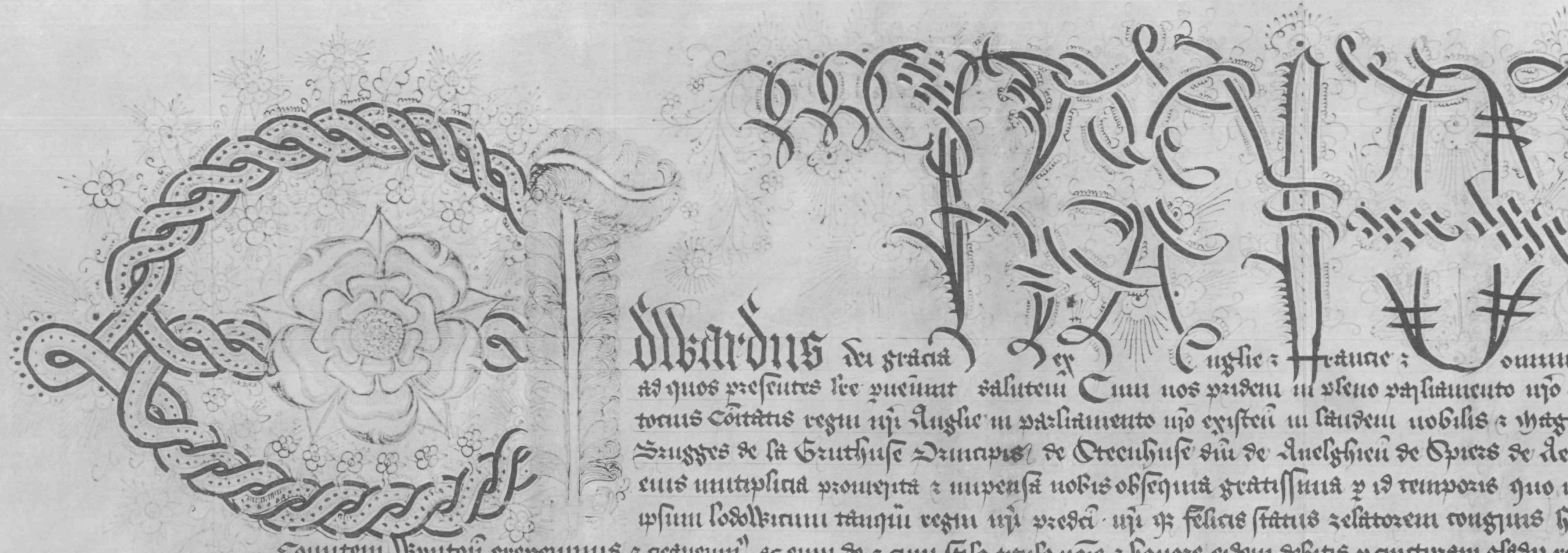

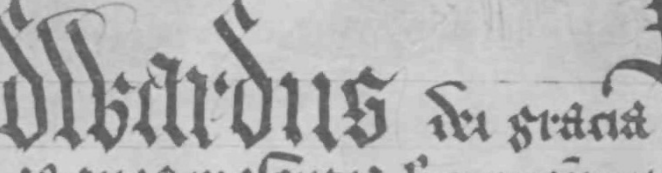

(x)

*

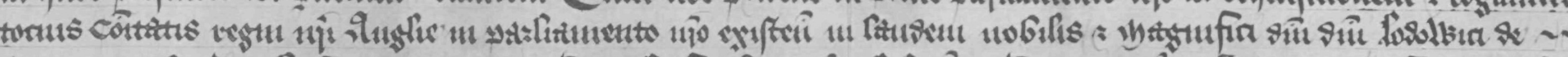

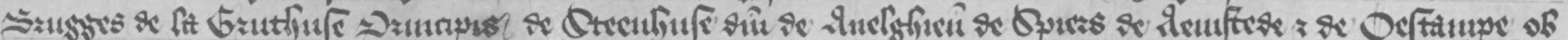

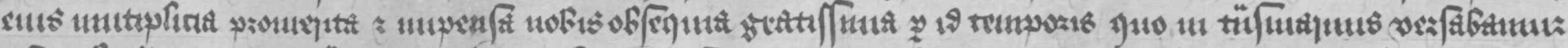

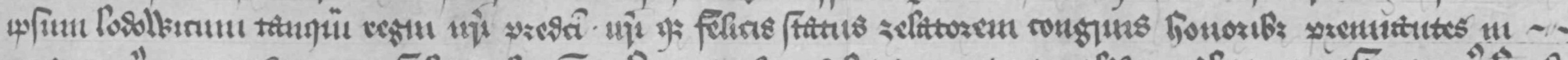

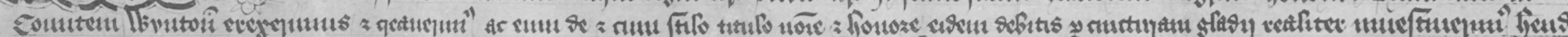

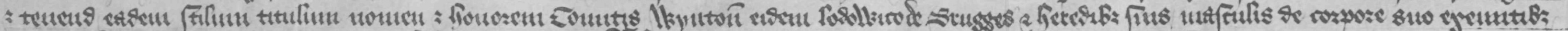

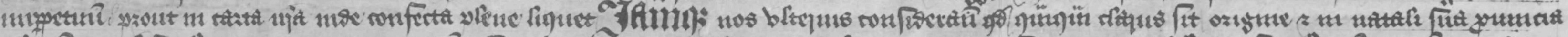

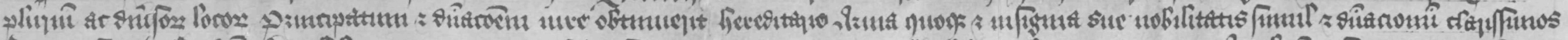

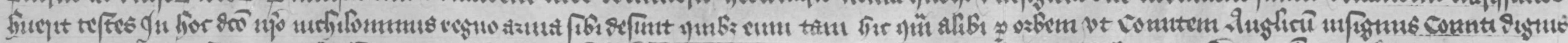

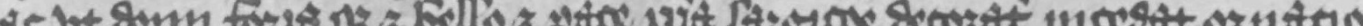
10

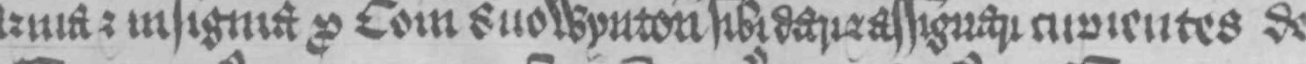

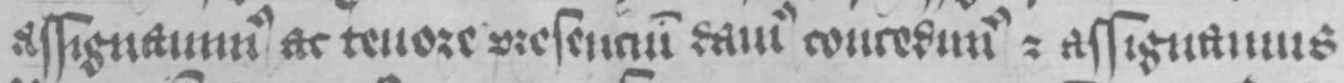

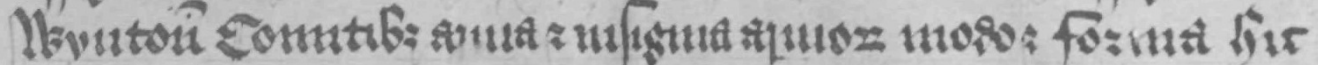
4:C

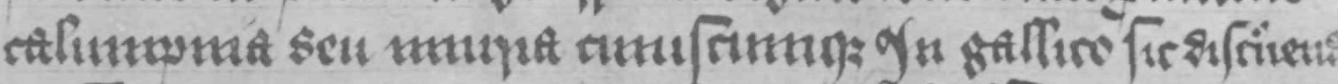

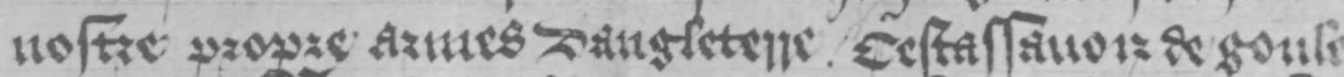

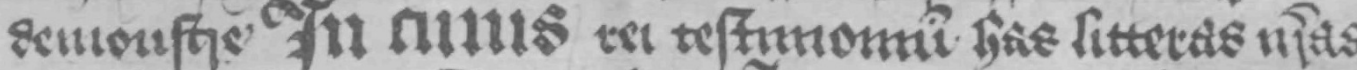

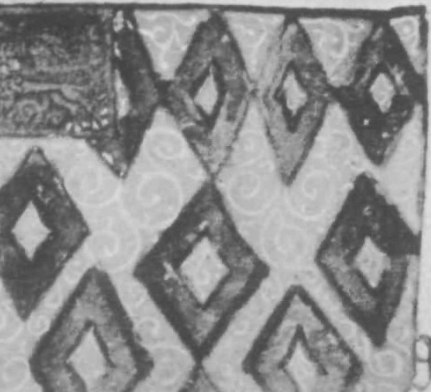
A

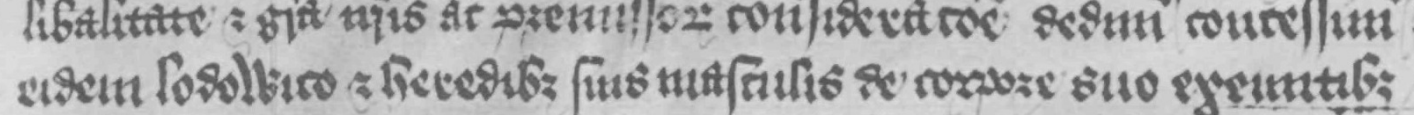

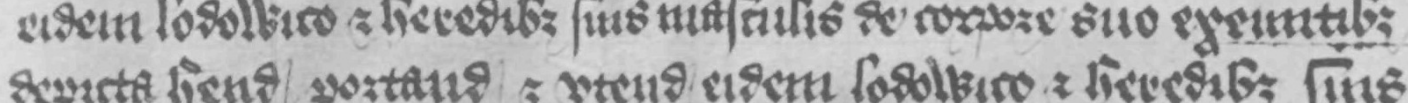

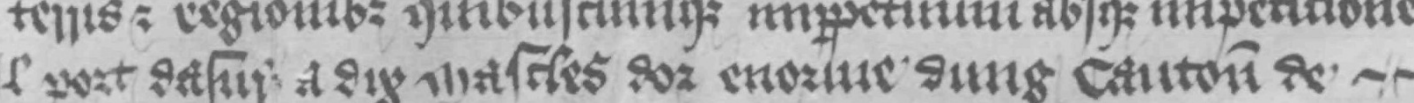

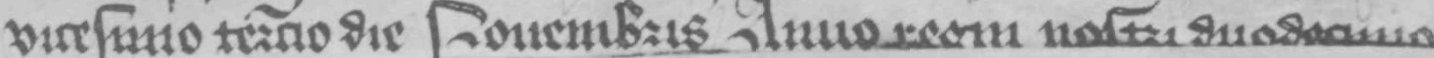

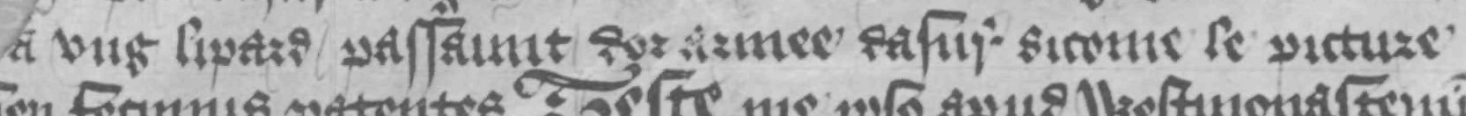

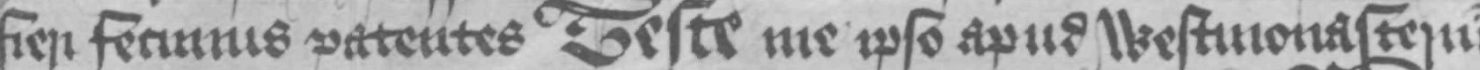

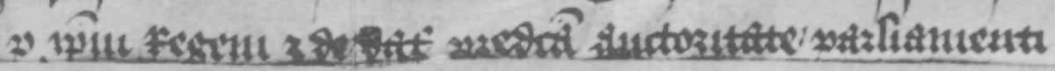
: Orbi.

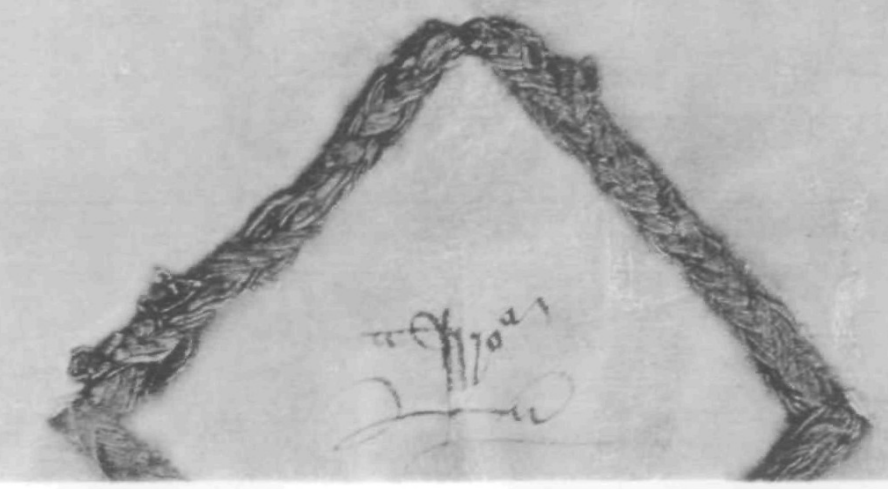


In September of the same year he again visited England as ambassador from the duke of Burgundy, when the opportunity arose for Edward to endeavour to requite his kindness. He was most honourably received at Calais, Dover, and other points on his journey to London, and paid a visit to the king at Windsor, where much entertainment was given in his honour. On St. Edwards's Day, the 13th October, the king in full Parliament caused Louis to be openly complimented by the Speaker for the "greate Humanyte and Kyndenes of the lorde Grauthause, shewed when the Kinge was in the Countries of Holland and Flaundres." He was also on the same occasion created Earl of Winchester, and invested with that dignity by the king in person by the girding of a sword after the ancient manner. The letters patent of Louis's creation then issued, and, borne by Garter king of arms in the procession, have been printed at length in Archaeologia by Sir Frederic Madden.

The king therein states that it has seemed good to him to decorate with fitting offices of honour " that most brave man and notable soldier Louis de Bruges, lord de la Gruthuyse, and prince of Steynhuyse, etc. who for his most grateful kindness has deserved whatsover is best from us." He then recounts the services rendered by him "when formerly we were driven by a happy fate into that province of our very dear brother the duke of Burgundy, over which the aforesaid Louis most worthily ruled," and advances him to the earldom of Winchester with the style, title, name, and honour due to the same, to have and to hold the same for himself and his heirs male for ever. For the proper maintenance of his new dignity the king further grants to the same earl Louis and his heirs aforesaid an annuity of $£ 200$, of which $£ 20$ was to be paid him by the sheriff from the farms, profits, etc. of the county of Southampton, and $£ 180$ from the customs and revenues of the port of Southampton by the officers and collectors of the customs and subsidies.

The letters patent are dated at the palace of Westminster on the day of Louis's investiture with the earldom of Winchester, namely, 13th October, 1472.

A few weeks later the king, by writ under the sign manual directed the chancellor of England to issue letters patent conferring upon Louis de Bruges, earl of Winchester, certain arms and ensigns of arms. By the kind permission of the Master of the Rolls, and the courtesy of the Deputy Keeper of the Public Records, the original writ with the arms depicted in the centre is here exhibited. The letters patent directed to be issued in accordance with this writ came into my possession a short time ago, and I have the honour of exhibiting them also. (Plate III.) As usual, they are written on vellum, and measure $19 \frac{5}{8}$ inches in width by 11 inches in depth (including the fold at the bottom), and the fragments of the 
great seal in green wax are still appended by a pink and blue plaited silk cord with an intertwined gold thread. The initial letter, which is elaborately drawn, encloses a large York rose, and has the upright stroke formed by an ostrich feather transfixing a small scroll. Both the initial and the other flourished initials of the first line are further ornamented with flowers.

The text of the grant is as follows:

Edwardus dei gracia Rex Anglie Francie et Dominus Hibernie Omnibus ad quos presentes litere pervenerint salutem. Cum nos pridem in pleno parliamento nostro ad requisicionem et rogatum tocius Communitatis regni nostri Anglie in parliamento nostro existentis in laudem nobilis et magnifici domini domini Lodowici de Brugges de la Gruthuse Principis de Steenhuse domini de Avelghieñ de Spiers de Aemstede et de Oestampe ob ejus mu[1]tiplicia promerita et impensa nobis obsequia gratissima per id temporis quo in transmarinis versabamur ipsum Lodowicum tanquam regni nostri predicti nostrique felicis status zelatorem congruis honoribus premiantes in Comitem Wyntoñ erexerimus et creaverimus ac eum de et cum stilo titulo nomine et honore eidem debitis per cincturam gladij realiter investiverimus. Habenda et tenenda eadem stilum titulum nomen et honorem Comitis Wyntoñ eidem Lodowico de Brugges et heredibus suis masculis de corpore suo exeuntibus imperpetuum prout in carta nostra inde confecta plene liquet. Jamque nos ulterius considerantes quod quamquam clarus sit origine et in natali sua provincia plurium ac diversorum locorum Principatum et dominacionem jure obtinuerit hereditario Arma quoque et insignia sue nobilitatis simul et dominacionum clarissimos habuerit testes In hoc dicto nostro nichilominus regno arma sibi desunt quibus eum tam hic quam alibi per orbem ut Comitem Anglicum insigniis Comiti dignis ornari deceat et agnosci proinde clarissime sue nobilitatis contemplacione ac ut domi forisque et bello et pace nostra largicione decoratus incedat ornacior arma et insignia pro Comitatu suo Wyntoñ sibi dari et assignari cupientes de liberalitate et gracia nostris ac premissorum consideracione dedimus concessimus et assignavimus ac tenore presencium damus concedimus et assignamus eidem Lodowico et heredibus suis masculis de corpore suo exeuntibus Wyntoñ Comitibus arma et insignia armorum modo et forma hic depicta habenda portanda et utenda eidem Lodowico et heredibus suis predictis in pace et in guerra in regnis locis dominiis provinciis terris et regionibus quibuscumque imperpetuum absque impeticione calumpnia seu injuria cujuscumque. In gallico sic discernenda Il port dasur a dix Mascles dor enorme dung Cantoñ de nostre propre armes Dangleterre: Cestassavoir de goules a ung lipard passaunt dor armee dasur sicome le picture demonstre. In cujus rei 
testimonium has litteras nostras fieri fecimus patentes. Teste me ipso apud Westmonasterium vicesimo tercio die Novembris Anno regni nostri duodecimo.

Per ipsum Regem et de data predicta auctoritate parliamenti.

IVE. ${ }^{a}$

The grant may be thus translated:

Edward, by the grace of God king of England and France and lord of Ireland, to all to whom the present letters may come Greeting. Since some time ago in our full Parliament, at the requisition and request of the whole Commons of our Kingdom of England appearing in our Parliament in praise of the noble and magnificent lord, lord Louis de Bruges de la Gruthuyse, prince of Steynhuyse, lord of Avilghem, Spiers, Hamste and Oostcamp, on account of his numerous deserts and most welcome kindnesses paid to us while we dwelled abroad, rewarding with fit honours as one zealous of our Kingdom aforesaid and of our happy state, we raised and created the same Louis earl of Winchester, and actually invested him by and with the style, title, name, and honour due to him by the girding of a sword. To have and to hold the same style, title, name, and honour of earl of Winchester to the same Louis de Bruges and the heirs male of his body begotten for ever, as in our charter issued on that occasion is fully made manifest.

Now we, further considering that, although he be illustrious in origin, and by birthright in his own province has obtained by hereditary right the principality and dominion of many and divers places, and also has arms and ensigns of his nobility and most illustrious witnesses of his dominions, nevertheless in this our said Kingdom he lacks arms, with which both here as elsewhere, through the whole world, it may become him as earl of Winchester to be adorned with the ensigns worthy of an earl, and in like sort to be recognised by the contemplation of his most illustrious nobility, and that at home and abroad, in war and in peace, he may go more ornately decorated by our bounty, desiring that arms and ensigns for his earldom of Winchester may be given and assigned to him, of our liberality and grace and in consideration of the premises we have given, granted, and assigned, and by tenor of [these] presents give, grant, and assign to the same Louis and his heirs male of his body begotten earls of Winchester, the arms and ensigns of arms in manner and form here depicted. To have, to bear, and to use to the same Louis and his heirs aforesaid, in peace and in war, in kingdoms, places, dominions, provinces, lands, and regions whatsoever for ever without hindrance, detraction, or injury of anyone. To be thus distinguished in French: Il port dasur

a The grant is also printed, from the Patent Roll, by Thomas Rymer in his Fredera, Conventiones, Literce, etc. (London, 1727), xi. 765 . 
a dix mascles dor enorme dung cantoñ de nostre propre armes d'Angleterre. That is to say, of gules, a leopard passant or, armed azure, as the picture sheweth. In witness of which thing we have made these letters patent. Witness my hand at Westminster, the 23rd day of November, in the 12th year of our reign. By the king himself, and on the date aforesaid, by authority of Parliament. Ive.

Before noticing the special provisions of this document it will be convenient to proceed with a further curious point in its history.

Louis de Bruges, to whom both the patent of nobility and this grant of arms were issued, had married, in 1455, Margaret, daughter of Henry van Borssle, lord of Vere and count of Grandpré. By her he had a son, John de Bruges, who, at his father's death on the 24th November, 1492, succeeded him as earl of Winchester.

On 8th May, 1500, the king of England, on pretence of avoiding the plague, went over to Calais and had an interview with the archduke Philip of Burgundy in the church of St. Peter without the town. After this, according to Hall, "the Frenche kyng Lewes the .xii. sent to vysite the kynge, the lorde Gronthouse governoure of Picardy, and the lorde Merneiliers, bayly of Amyas, whiche declared to the kyng the getting of Millayn, and takyng of the duke, whiche lordes were highly feasted and with great rewardes departed." " The king returned to England on 16 th June.

The "lord Gronthouse" here mentioned was John de Bruges, earl of Winchester. He had been chamberlain to Louis XI. and chancellor of France, and among other offices he was at this time grand master of the Crossbowmen of France. In the face of Hall's statement as to the favourable reception by Henry VII. of him and his fellow ambassador, it is not easy to explain the following memorandum, which is endorsed on the grant of arms under notice:

Vacant iste litere patentes quia sursumreddite et restitute fuerunt ad manus domini nostri Regis Henrici septimi apud villam Cales anno regni sui . $\mathrm{xv}^{\circ}$. ea intencione ut cancellentur et dampnentur. Ideo presentes litere sic ut premittitur sursumreddite et restitute cancellantur et dampnantur.

A similar entry is made against the enrolment of the letters patent on the Patent Roll, where the document itself is also crossed out.

We further learn that the surrender of this grant of arms by John de Bruges

a The Vnison of the two noble and illustre famelies of Lancastre \& Yorke, etc. (London, 1548). The politique governaunce of Kyng Henry vii. f. lii. 
accompanied his resignation of the earldom of Winchester conferred upon his father and his heirs male by Edward IV. by tendering to the king the letters patent then granted; for against the enrolment of this on the Charter Roll is a like entry to that made on the Patent Roll against the grant of arms.

What were the reasons that led John de Bruges to take this step I have not been able to learn, but, looking to the condition of affairs on the continent, and the relations existing between England, France, Spain, etc. it is possible that earl John of Winchester desired to renounce his fealty to the king of England for reasons similar to those which caused Ingelram sire de Coucy and earl of Bedford to resign his companionship of the Order of the Garter together with his fealty to Edward III. in $1377 .^{\mathrm{a}}$

Here I must leave the historical aspect of the case and return to a discussion of several interesting heraldic questions.

The arms of Louis de Bruges, as we learn from his seal, were; Quarterly, 1 and 4, or, a cross sable (Gruthuyse); 2 and 3, gules, a saltire argent (Van der Aa). ${ }^{\mathbf{b}}$ The arms, therefore, which were granted him by Edward IV. as "ensigns worthy of an earl" for the "arms and ensigns of his earldom of Winchester," belong to the class which some heralds have termed "arms of succession or feudal arms," borne by the holders of certain lordships or estates. "The arms under notice, it will be observed, are made up of the mascles borne by Roger de Quincy, who was earl of Winchester from 1235 to 1264, but on a field azure instead of gules. This change of tincture was doubtless made to allow of the augmentation of a canton, "de nostre propre armes D'Angleterre," as the king describes it, that is, of gules with a lion passant gardant or.

To find a case exactly parallel to this is by no means easy. Of later examples, there are, of course, instances, but I do not know of another medieval grant of an English dignity to a foreigner, accompanied by a grant of arms or the right to bear arms pertaining to such dignity. Of grants of arms under the great seal there are a number enrolled on the Patent, Vascon, and Charter Rolls, amongst which may be cited as familiar to antiquaries those granted by Henry VI. to his colleges at Eton and Cambridge. ${ }^{c}$ Three instances of letters patent ennobling foreigners and granting them arms are printed in Rymer's F'odera ${ }^{d}$ from the Vascon Rolls, and the writ for another in favour of Arnald and Grimond de Bordeu is here exhibited

a Thomas Rymer, Fodera, Conventiones, Litterce, etc. (London, 1728), vii. 172.

b G. Demay, Inventaire des Sceaux de la Flandre (Paris, 1873), i. 89 [No. 662].

- Both grants are printed in Bentley's Excerpta Historica, or Illustrations of English History (London, 1831), 47, 362.

d Vols. x. 718, xi. 81, and xi. 101.

VOL. LVI. 
in illustration by the courtesy of the Deputy Keeper. But none of these grants conferred any English title or dignity. Two similar writs under the sign manual of Henry VI. are preserved in the Record Office for the issue of letters patent ennobling and granting arms to Nicholas Cloos and to Roger and Thomas Keys for their services in connection with the building of the king's colleges at Cambridge and Eton. ${ }^{a} \quad$ It is clear from these that ennobling simply raised a man to the rank of gentleman and empowered him to bear arms, and did not necessarily make him even an esquire. One more grant may be mentioned, of an annuity of $£ 100$ under letters patent of Edward IV. in 1461 to Francis, bishop of Terni, and authorising him and his nephews, Bartholomew and Thomasinus, to bear a white rose (divisam nostram) on their arms. ${ }^{b}$ Here again, however, no dignity or title was conferred.

Perhaps our nearest parallel to the grant to Louis de Bruges is that made in 1414, by Henry V. to his brother John, earl of Kendal and duke of Bedford, of the reversion of the earldom and lordship of the honour of Richmond, "cum armis integris eisdem Comitatui Honori et Dominio de Richmond annexis et pertinentibus." c

So far, unfortunately, I have not been able to find any instance of the use by the duke of Bedford of the arms of his earldom and honour of Richmond, and it is somewhat uncertain what they might have been. The first earl of Richmond whose arms we know was Peter de Braine, son of Robert, count of Dreux and Braine. He married, in 1213, Alice, daughter of Constance, de jure countess of Richmond and duchess of Brittany (ob. 1201), by her third husband, Guy de Thoumars, and thus became earl of Richmond and duke of Brittany jure uxoris. His own arms were checky or and azure, to which he added on his marriage $a$ quarter ermine, for Brittany. His son and grandson, both earls of Richmond, bore the same arms with a bordure gules, on which the next earl, John de Bretagne III. placed lions of England, out of compliment to his mother, a daughter of Henry III. In each instance the ermine quarter is "over all."

By the death of the fourth John, earl of Richmond, in 1341, the earldom passed to his half-brother John, called "de Montfort," but in 1342 it reverted to the Crown and was conferred by Edward III. upon his son John of Ghent, who held it until 1372. It was clearly on this account that John of Ghent as earl of Richmond differenced his paternal arms, France Ancient and England quarterly with a label ermine. In 1372 the earldom of Richmond was surrendered by John

a Both writs are printed in Bentley's Excerpta Historica, 49, 364. There is no record of their enrolment either or the Patent, Charter, or Close Rolls.

b Thomas Rymer, Fodera, Conventiones, Iiterce, etc. (London, 1727), xi. 479, 480.

- Rotuli Parliamenturum, iv. 41. 
of Ghent and conferred upon John de Montfort II. duke of Brittany, whose arms were simply ermine. His third wife was Joan of Navarre, who after his death married Henry, duke of Lancaster, afterwards Henry IV. Their son John, duke of Bedford, is the prince upon whom his brother, Henry V., conferred the reversion of the earldom and honour of Richmond in 1414. The arms of this prince were France Modern and England quarterly with a label, of which two points were ermine, and three points azure charged with fleurs-de-lis or. This I would venture to call a label of Richmond and Lancaster. The seal, however, whereon this label first occurs is anterior to the assumption by the prince of any title, and as a label wholly of Richmond was borne by another brother, Thomas, duke of Clarence (1412-1421), it seems as if in both cases the label was borne in memory of John of Ghent, and had lost its significance with regard to the earldom of Richmond. This is confirmed by the fact that later holders of the earldom did not use any ermine in their arms or labels. The question, therefore, as to what were the arms of the earldom and honour of Richmond cannot yet be regarded as satisfactorily settled.

That the arms of the holders or possessors of certain of the ancient earldoms or lordships were regarded as those of the earldom or lordship, and as hereditary with it, is borne out by a number of interesting examples. A clear case in point, because no descent of a family is involved, is that of the lordship of Man. This was granted in 1333 to William de Montacute, earl of Salisbury, and the well-known arms of the lordship are quartered with Montacute on the seal of his son and successor William. In 1395 the lordship was purchased by William le Scrope, who on his seal assumed the arms of Man and bore them alone, differenced with his label as eldest son of his father.

The lordship of Man was forfeited by Scrope in 1400 and granted to the earl of Northumberland, but again forfeited. It eventually passed in 1406 to Sir John Stanley, in whose family it remained until 1736. On the stall-plate of Thomas Stanley, first earl of Derby, 1485-1504, the three legs which form the arms of Man are borne as a quartering, and they were so used by his son and successor.

The banners of arms that appear on the seals of Walter Hungerford, lord of Heytesbury and Homet, and of William, lord Fitzhugh and of Marmion, may be instances of a similar kind.

The arms of the county palatine of Chester, azure, three yarbs or, used by Ranulf de Blondeville, earl of Chester, 1181-1232, have ever since been recognised as such. They are so shown for instance on the second great seal of Henry IV. On the counter-seal of Richard III. for the county palatine, and that of 1609 , they are 
impaled by the royal arms. On later seals, temp. Charles I., of 1660, and 1706, the garbs alone appear.

The arms of the county palatine of Lancaster, England with a label of France, afford another instance. Originally adopted by Edmund Crouchback, earl of Lancaster, 1265-96, as his personal arms, they have continued to be recognised as the arms, first of the earldom, then of the duchy, down to the present day.

So too with the arms of the earldom and dukedom of Norfolk, England with a label of three points argent. These were first used by Thomas de Brotherton, son of Edward I., created earl of Norfolk in 1312. In 1397 Thomas Mowbray, great grandson of Thomas de Brotherton, and earl of Nottingham, was made earl marshal, and a few months later created duke of Norfolk. On his seal he impales the arms of Edward the Confessor, which he was specially authorised to wear, with those of Norfolk, i.e. de Brotherton. His three immediate descendants and successors in the dukedom also laid aside the Mowbray arms for those of Norfolk. On the seal of one of these, John Mowbray, 1432-1461, the Norfolk arms are placed between two shields, one of the arms of the earldom of Surrey and Warrenne (Checky or and azure), the other of the earldom of Arundel (Gules, a lion rampant or) or perhaps Mowbray (Gules, a lion rampant argent). From behind each shield rises an ostrich feather with a chain laid along the quill. John Howard, who succeeded to the dukedom in 1483, quartered Norfolk with the arms of Howard. The later dukes have also retained the Norfolk arms as one of their quarterings, as well as those of Surrey.

In an inventory of the goods and chattels seized at Pleshy on the death of Thomas of Woodstock, son of Edward III., who was created earl of Buckingham in 1377, and duke of Gloucester in 1385, mention is made of a white halling with red and black borders powdered with swans (the De Bohun badge) and " the arms of Hereford." a If we may take as evidence one of the duke's seals, and the splendid brass to his wife, Eleanor de Bohun, at Westminster, the arms of Hereford were those assigned to Milo of Gloucester, created earl of Hereford in 1141, gules, two bends, one or the other argent. The Rev. C. Boutell has suggested that the gold bend with silver cotises which have formed part of the arms of De Bohun from certainly the time of Humphrey de Bohun, earl of Hereford and Essex 1220-1275, are derived from Milo's bendlets, ${ }^{\text {b }}$ which is very likely. In that case the arms of the earldom of Hereford may be said to have survived down

"Archaeological Journal, liv. 289.

b Heraldry Historical and Popular, 3rd edition (London, 1864), 155. 
to $1473-4$, when their use as a quartering by the earls was abandoned by Henry Stafford, duke of Buckingham, who then held the title, for a reason to which I shall presently refer.

The early seals of the De Bohuns introduce us to another shield of an earldom, that of Essex, quarterly or and gules. This is found on either side of the De Bohun arms on the seal of Humphrey de Bohun, who became earl of Essex jure matris in 1228; also on the seal of his great grandson, another Humphrey, who was earl of Hereford and Essex 1298-1321-2.

Another suggestion of $\mathrm{Mr}$. Boutell ${ }^{\mathrm{a}}$ that the golden lioncels on an azure field borne by the De Bohuns owe their origin to the marriage of an early member of the family to the sister of another feudal lord, Walter of Salisbury, reminds us of the arms of the earldom of that place. These were first borne by William Longespée, who became earl of Salisbury in right of his wife, the countess Ela, in 1198, and are beautifully sculptured on his effigy. After his death in 1226 the earldom seems to have reverted to his widow, who survived both her son and grandson until 1261, when her great granddaughter Margaret, wife of Henry de Laci, earl of Lincoln, became de jure countess of Salisbury. On her death in 1310 her only surviving daughter and heiress Alice, wife of Thomas earl of Lancaster, seems to have become countess of Salisbury, and by the death of her father the same year countess of Lincoln also. The earl of Lancaster was beheaded in 1322, when all his honours were forfeited and his wife was compelled to convey all her inheritance to the king. The earldom of Salisbury thus lapsed to the crown. In 1337 it was conferred on William, lord Montacute, in whose family it descended on the death of her father Thomas, earl of Salisbury and count of Perche, in 1428, to Alice, baroness Montacute and suo jume countess of Salisbury. She had married in 1424 Richard Nevill, son of Ralph, earl of Westmorland, who thus became earl of Salisbury. On his beautiful seal he quarters his wife's arms "for Salisbury" with his own, and flanks the shield with two lesser shields, one of which bears the ancient arms of Salisbury, the lioncels of William Longespée.

I should like to cite just one more instance, because it appears to combine the arms of the earldoms of Buekingham, Hereford, Northampton, and Stafford. This is exemplified by the seal of Humphrey Stafford, who succeeded his father as earl of Stafford in 1403. In 1442, jure matris, Anne, daughter and heiress of Thomas of Woodstock, he became earl of Buckingham, Hereford, and Northampton. Thomas of Woodstock, as we have already seen, was created earl of Buckingham

ap. cit. 154. 
in 1377, but his other dignities of Hereford and Northampton passed to him in right of his wife, Eleanor, daughter and coheir of Humphrey de Bohun, who became earl of Northampton in 1360, and by the death of his uncle in 1361 earl of Hereford also. Thus the quarterings on Humphrey Stafford's seal: 1. Thomas of Woodstock; 2. Bohun of Hereford; 3. Bohun of Northampton; and 4. Stafford, are satisfactorily accounted for.

The grandson of Humphrey, Henry Stafford, second duke of Buckingham, in a chapter of the Office of Arms held on 18th February, 1473-4, was allowed to bear the arms of Thomas of Woodstock alone as being a nobleman "who is descended lenyalle Ineritable to iij or iiij Cotes \& afterward is ascended to a Cotte neire to the King and of his blood royal." "a

It will be seen by these examples, which might easily be multiplied, that there can be little or no doubt as to the hereditary character of the arms of many of the earldoms; the grant therefore to Louis de Bruges of a differenced shield of the arms of a former earl of Winchester is an interesting survival.

It only remains for me in conclusion to say a few words as to the manner in which such grants as that under notice were issued. In the first place the king issued a writ under the sign manual reciting the text of the grant and directing the chancellor to issue the letters patent. This particular document in favour of Louis de Bruges is before you, and, as may be seen, it contains an illumination of the arms to be granted. The letters patent issued in accordance with it are also before you. Finally the letters patent were enrolled, in this case on the Patent Roll, where the arms are again illuminated. We have extant, therefore, in this case the complete series of documents. The same fortunately occurs with regard to the grants made by Henry VI. to his colleges at Eton and Cambridge, the originals of which, it will be remembered, were shown in the Heraldic Exhibition in 1894. The writs for the issue of both are attached to the enrolment on the Charter Roll, to enable the illuminator to fill up the spaces which still remain blank on the roll for the arms.

These three are, I believe, the only examples known where the writ, letters patent, and enrolment of a medieval grant of arms are still in existence. The document which I have been able to exhibit may therefore fairly claim to be one of exceptional interest.

- British Museum, Cott. MS. Titus C. i. 404. 